\title{
Watershed management of the Atibaia River Basin based on the elaboration of environmental scenarios
}

\author{
A. C. Demanboro ${ }^{1}$, G. L. Laurentis ${ }^{2}$, S. C. Bettine ${ }^{1}$, R. M. Longo ${ }^{1}$ \\ \& E. M. Mediondo 2 \\ ${ }^{1}$ Centre of Exact and Environmental Sciences and Technologies, \\ Pontifical Catholic University of Campinas, Brazil \\ ${ }^{2}$ Hydraulics and Sanitation Department, \\ Engineering School of Sao Carlos, University of Sao Paulo, Brazil
}

\begin{abstract}
Water is related to the survival of organisms and to the development of human beings. Due to the complexity of ecosystems, the comprehension of the territory through environmental diagnosis is necessary. This approach is the first step to making environmental planning able to sustain the integrated analysis on the scope of river basins study and management. This paper provides a theoretical analysis of the role of green areas in the basin and urban context. Also, three prospective scenarios of forest best management practices for the Atibaia River Basin, Sao Paulo there were elaborated. Soil stability and water resources aspects were considered in order to combine the management of water resources and environmental conservation. The scenarios elaborated were Tendency Scenario, Management Scenario and Conservation Scenario. The best results were achieved through the Conservation Scenario, where ecological restoration, water resources protection and the improvement of the population's life quality were highlighted.
\end{abstract}

Keywords: environmental indicators, prospective scenarios, urban areas, water resources. 


\section{Introduction}

Projections from the United Nations estimate that by 2030 more than one half of the population of the world (in that period, about five billion people) will live in urban areas. So, the future of mankind depends on attitudes taken now in order to organize and reduce this uncontrolled and unplanned growth. Also, the reduction of environmental damage caused by cities is expected, in order to reach sustainability and to explore new opportunities in those complex urban systems $[1,2]$.

Nowadays, principles that guide water planning have changed. The attributes of planning like flood and land-use are on the agenda to deal with the complexity of this problem. There is a need for alternative techniques that allow the conciliation of environmental planning aspects (flood and pollution), with social and ecological attributes [3]. Pickett et al. [1] defend the transition from sanitary to sustainable cities.

Related to the increase on the impervious surface of the basin, the amount of rain converted into runoff can vary from $20 \%$ to $50 \%$, which has a direct impact on the rates of water infiltration [4].

Ross [5] proposed the idea of environmental fragility mapping, also known as Eco-dynamic Mapping, one theory based on studies realized by Tricart [6]. So, the environment is classified according to its stability (or instability) conditions. This concept is related to the degree of instability resulting from human activities, where the landscape becomes more vulnerable to geomorphologic and hydrologic transformations.

According to this, urban development itself has significant impacts on river landscapes and alterations on the hydrology of urban streams [7, 8]. The main effects on urbanization, due to the increase of impervious surfaces, are alterations in drainage density, increases in peak discharges, surface runoff increases, erosive processes, channel enlargement, variations in stream temperatures, fauna diversity and a decrease in integrity, reduction of infiltration and less groundwater recharge [7-10].

Rainwater drainage is one of the ecosystem services that occur in urban areas [11] due to the urban ecosystems [12] or urban green and blue infrastructure [13, 14]. This covers area such as parks, urban forests, cultivated lands, wetlands, lakes/seas and streams.

Environmental aspects demand a dynamic approach instead of static readings of the object of study, because the processes are constantly changing and are influenced by a combination of actions and actors. This approach makes possible a long-term impact evaluation, once the horizon of analysis varies as a function of a temporal scale $[15,16]$. Mendiondo et al. [17] propose the use of scenarios when working with planning and management of river basins, as an attempt to promote the impact reduction and disaster prevention in those areas, through the recuperation, restoration and rehabilitation of urban rivers and watersheds.

This paper aims to propose and analyze alternative scenarios of land-use and natural resource exploration at the Atibaia River Basin, Sao Paulo, focusing on the mitigation in urban areas and environmental protection. The two main 
objectives are (i) to provide a theoretical basis related to urban drainage and natural areas; (ii) the proposition of three prospective scenarios of management in a specific river basin, based upon the best management practices to the restoration of the river and the forest ecosystems.

\subsection{Study area}

This study relates to the Atibaia River Basin, located between the coordinates $22^{\circ} 40^{\prime}$ and $23^{\circ} 20^{\prime}$ south and $47^{\circ} 20^{\prime}$ and $46^{\circ} 00^{\prime}$ west, with an area of $2,816,40 \mathrm{~km}^{2}$. The basin is composed totally or partially by 16 municipalities of the Sao Paulo state, while there is only one municipality of the Minas Gerais state. Figure 1 represents the location of the basin between these two states.

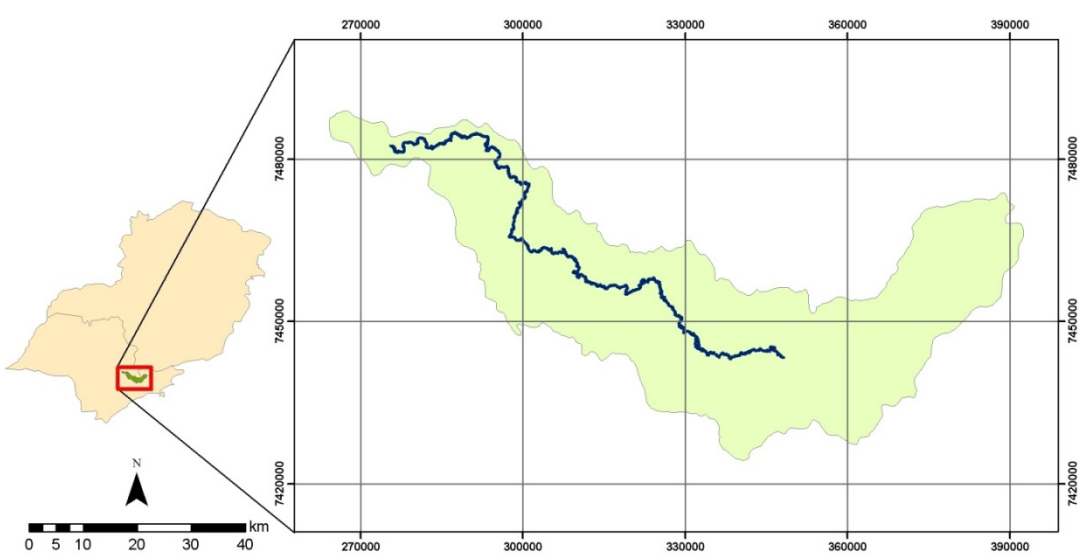

Figure 1: The study area. Source: Laurentis et al. [21].

The Atibaia River originates in the municipality of Bom Jesus dos Perdões, from the confluence of the rivers Cachoeira and Atibainha, and is 182 kilometers in length. It is one important river from south east Brazil. The basin is in the intermediate section of the Tietê River Basin, composing the Hydrographical Region of the Paraná River Basin [18, 19].

The climate is warm, temperate and rainy, influenced by Polar and Tropical Atlantic air masses, with a predominance of southern winds [20]. Rainy months are December, January and February, with a mean precipitation of $250 \mathrm{~mm} / \mathrm{month}$. Months like June, July and August are considered the driest; the average amount of rain is about $80 \mathrm{~mm} /$ month. The drought period goes from April to September, while from October to March the weather is considered wet [18].

\section{Methods}

The following lines provide information related to the criteria adopted during the selection of the environmental indicators and in the elaboration of prospective scenarios. 


\subsection{Environmental indicators selection and calculation}

The environmental indicators considered on this approach are related to forest best management practices on a river basin scale, and also to soil and water conservation measures in both urban and non-urban areas. It is expected that the improvement of the environmental quality of the basin could add biodiversity and ecological gains from a local to a regional scale.

The selection of the indicators is shown in Table 1. The data obtained for the Atibaia River Basin are based on the mapping realized by Laurentis et al. [21], which refers to the environmental diagnosis of the area. Once the indicators are selected, spatial distribution of the vegetation coverage on the basin has been made, according to each scenario characteristics. This has allowed visual and quantitative analysis relating to the augmentation or reduction of forested areas in urban or rural areas, considering the watershed as a whole.

Table 1: $\quad$ Indictors selected in this study.

\begin{tabular}{|c|c|c|}
\hline $\begin{array}{c}\text { Type of } \\
\text { indicator }\end{array}$ & Indicator & Source of data \\
\hline \multirow{3}{*}{ Land use } & Urbanization of the basin & Chart of land use \\
\hline & Population density & Characterization of the area \\
\hline & Anthropic intervention in the basin & Chart of land use \\
\hline $\begin{array}{l}\text { Protected } \\
\text { Areas }\end{array}$ & Anthropic intervention in PP & Chart of land use + PP Chart \\
\hline \multirow{3}{*}{$\begin{array}{c}\text { Water } \\
\text { Resources }\end{array}$} & Urban use related to total use & Characterization of the area \\
\hline & Industrial use related to total use & Characterization of the area \\
\hline & Rural use related to total use & Characterization of the area \\
\hline \multirow{4}{*}{ Vegetation } & Natural vegetation remained & Chart of land use \\
\hline & Vegetation in PP & $\begin{array}{l}\text { Chart of land use }+ \text { Chart of } \\
\text { waterborne }\end{array}$ \\
\hline & Vegetation outside PP & Chart of land use + PP Chart \\
\hline & Vegetation in each compartment & $\begin{array}{c}\text { Chart of land use }+ \text { Chart of } \\
\text { the Compartments }\end{array}$ \\
\hline Fragility & Potential Fragility & $\begin{array}{c}\text { Chart of the Potential } \\
\text { Fragility } \\
\end{array}$ \\
\hline
\end{tabular}

\subsection{Scenario elaboration}

Three prospective scenarios were elaborated for the basin, with prognostics up to 2020. The scenarios are the Tendency Scenario, the Management Scenario and the Conservation Scenario. The first of them, the Tendency Scenario, could be defined as a continuation of the present pattern of occupation and degradation of the basin. No measures relating to the improvement of the environmental quality and human well-being were taken, and there was a continuation of natural resource degradation and uncontrolled population growth. Also, the stagnation of 
the political responses of government and society to these issues is assumed [22, 23].

The second one, the Management Scenario, focused on water resource protection, where the handling of the basin was adequate for the conservation of the water bodies and headwaters. Under this scenario, population and urban growth rose as Tendency Scenario projections. On the other hand, there was an improvement in the vegetation cover of the basin, once the reforestation of the totality of the Permanent Preservation (PP) areas, according to definitions and criteria of the Brazilian Federal Law number 4.771/65 [24] was adopted. This measure contributed to the reduction of human intervention in the basin, as well as to the environmental fragility, a product of the Eco-dynamic Mapping [6] due to the reforestation of those areas.

Finally, the Conservation Scenario aimed at the restoration and conservation of both water and natural resources, with a bit more consciousness about human impact mitigation, such as urban and population growth. This was an alternative to the Management Scenario, because, beyond the recuperation of PP areas, conservation units were considered an effective measure of environmental protection and human well-being improvement. There was no deforestation and natural vegetation was recovered on three types of hot spots areas: (1) PP areas; (2) total of areas with environmental fragility classified as very high; (3) areas with environmental fragility considered high and under protection inside conservation units. In addition, municipal and society actions were taken. Table 2 shows the dynamic of the indicators used in this evaluation for the proposed scenarios, where each one can suffer high reduction (- -), small reduction $(-)$, stagnation $(0)$, small increase $(+)$ or high increase $(++)$.

\section{Results}

\subsection{Scenario comparison}

The results obtained for the Tendency Scenario showed a high population growth allied to the economic appropriation of natural resources. There was more deforestation and no increase in the amount of vegetation under any kind of legal protection. An increase both in the impervious surface coverage was expected, and consequently in surface runoff, as well other impacts on the hydrologic cycle and vulnerability to water-related extreme events.

For the Management Scenario, a similar urban growth was observed, but human intervention in protected areas was reduced, since in this scenario the restoration of the PP areas occurred and all the springs were protected. Consequently, the vegetation cover increased due the reforestation activities along the rivers. Also, the instability of the soils on the basin was reduced near the streams. These actions contribute to a better conservation of the water resources and provide benefits to urban areas, such as erosion reduction, water flow regulation and pollution reduction.

In the Conservation Scenario, the best conditions for ecological restoration, environmental conservation and urban drainage management were achieved, 
Table 2: $\quad$ Variation of the indicators for the proposed prospective scenarios.

\begin{tabular}{|c|c|c|c|c|}
\hline \multirow{2}{*}{ Indicators } & \multirow{2}{*}{ Suggested Units } & \multicolumn{3}{|c|}{ Scenarios } \\
\hline & & TEN & MAN & $\mathrm{CON}$ \\
\hline $\begin{array}{l}\text { Urbanization rate } \\
\text { of the basin }\end{array}$ & $\mathrm{Km}^{2} /$ year & + & + & - \\
\hline Population density & Inhab $/ \mathrm{km}^{2}$ & + & + & - \\
\hline $\begin{array}{l}\text { Human } \\
\text { intervention in the } \\
\text { basin }\end{array}$ & $\begin{array}{l}\mathrm{Km}^{2} / \mathrm{km}^{2} \text { total of the } \\
\text { basin }\end{array}$ & + & - & -- \\
\hline $\begin{array}{l}\text { Natural vegetation } \\
\text { cover }\end{array}$ & $\begin{array}{l}\mathrm{Km}^{2} / \mathrm{km}^{2} \text { total of the } \\
\text { basin }\end{array}$ & - & + & ++ \\
\hline $\begin{array}{l}\text { Environmental } \\
\text { fragility (high) } \\
\text { total }\end{array}$ & $\begin{array}{l}\mathrm{Km}^{2} / \mathrm{km}^{2} \text { total of the } \\
\text { basin }\end{array}$ & 0 & - & -- \\
\hline $\begin{array}{l}\text { Environmental } \\
\text { fragility (very } \\
\text { high) total }\end{array}$ & $\begin{array}{l}\mathrm{Km}^{2} / \mathrm{km}^{2} \text { total of the } \\
\text { basin }\end{array}$ & 0 & - & -- \\
\hline $\begin{array}{l}\text { PP areas to be } \\
\text { restored }\end{array}$ & $\mathrm{Km}^{2} / \mathrm{km}^{2}$ of PP areas & + & - & -- \\
\hline $\begin{array}{l}\text { Natural vegetation } \\
\text { cover inside PP } \\
\text { areas }\end{array}$ & $\mathrm{Km}^{2} / \mathrm{km}^{2}$ of PP areas & - & ++ & ++ \\
\hline
\end{tabular}

once the watershed was more equilibrated and able to adapt itself to adverse conditions. Also, in this case, the disaster risk management and reduction reached its best results, because urbanization was planned better and there was an increase in the amount of permeable areas. For this simulation, there was an expansion of the vegetation cover, according to environmental policies at a municipal scale, and due to an increase in the amount of vegetation in protected areas. In this scenario, the instability of the soil also reached the lower values.

Figure 2 shows the interpretation that the highest values of natural vegetation coverage and the lowest values of human intervention were obtained on Conservation Scenario. The Management Scenario acts as a transition condition, with characteristics of the other situations mixed in a context of minimal conditions of water management. 


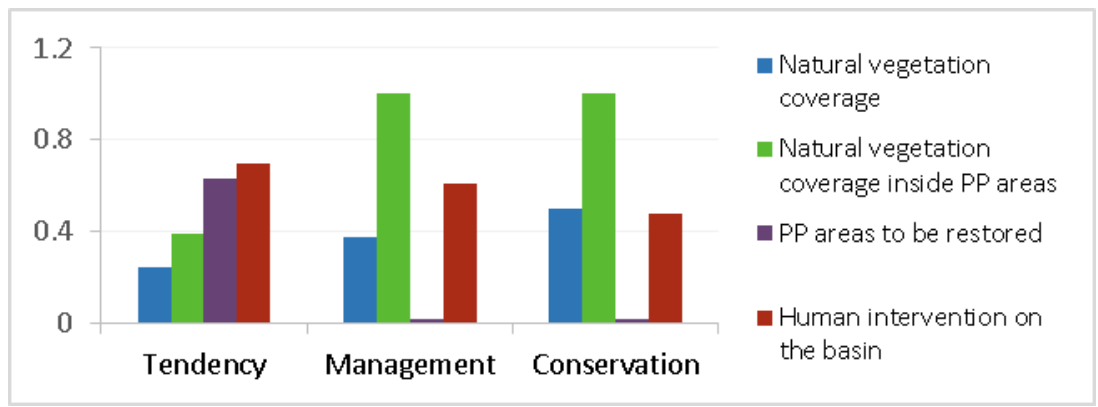

Figure 2: Comparison between the values of the indicators.

In Figure 3 it is possible to see the behavior of the reduction of the environmental fragility from one scenario to another, where the Conservation Scenario shows an increase in land stability.

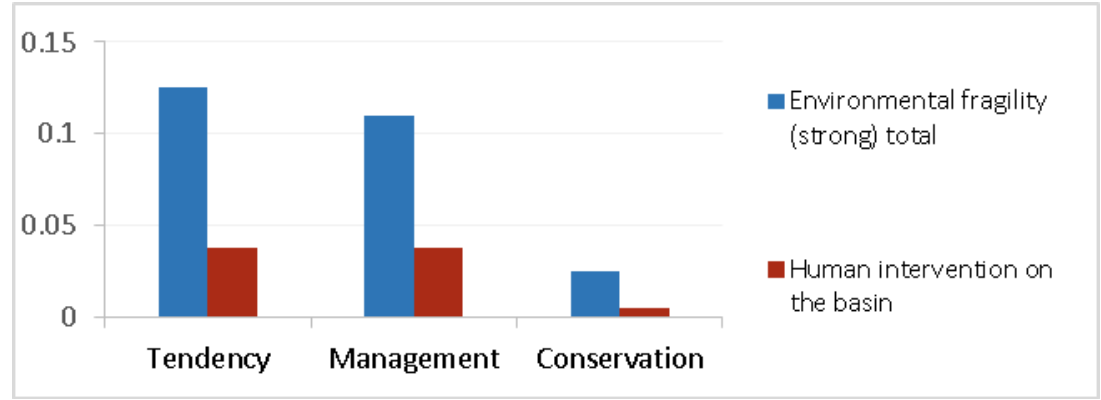

Figure 3: Evolution of the environmental fragility in each scenario.

According to the data obtained from the scenarios, it was possible to observe that the most favorable scenario was the Conservation one, where natural vegetation coverage reached convenient values so that water retention, infiltration and regulation are optimized. Nevertheless, as a transitional measure, the adoption of the Management Scenario could be reasonable, once the restoration of the PP areas promote an increase in the amount of vegetation of the basin and, in the mean time, protects the water bodies. The Tendency Scenario confirms that the actual way of using the natural and water resources, as well the population growth and urban expansion are inadequate and unsustainable.

The spatial distribution of vegetation coverage in the scenarios is represented in Figure 4. In Tendency Scenario (item a) it can be observed that urban areas remain with less presence of vegetation, and rural areas are the main provider of natural areas to the basin.

On the other hand, in the Management Scenario (b) representation, it is possible to see the augmentation of vegetation presence in the urban areas. This 

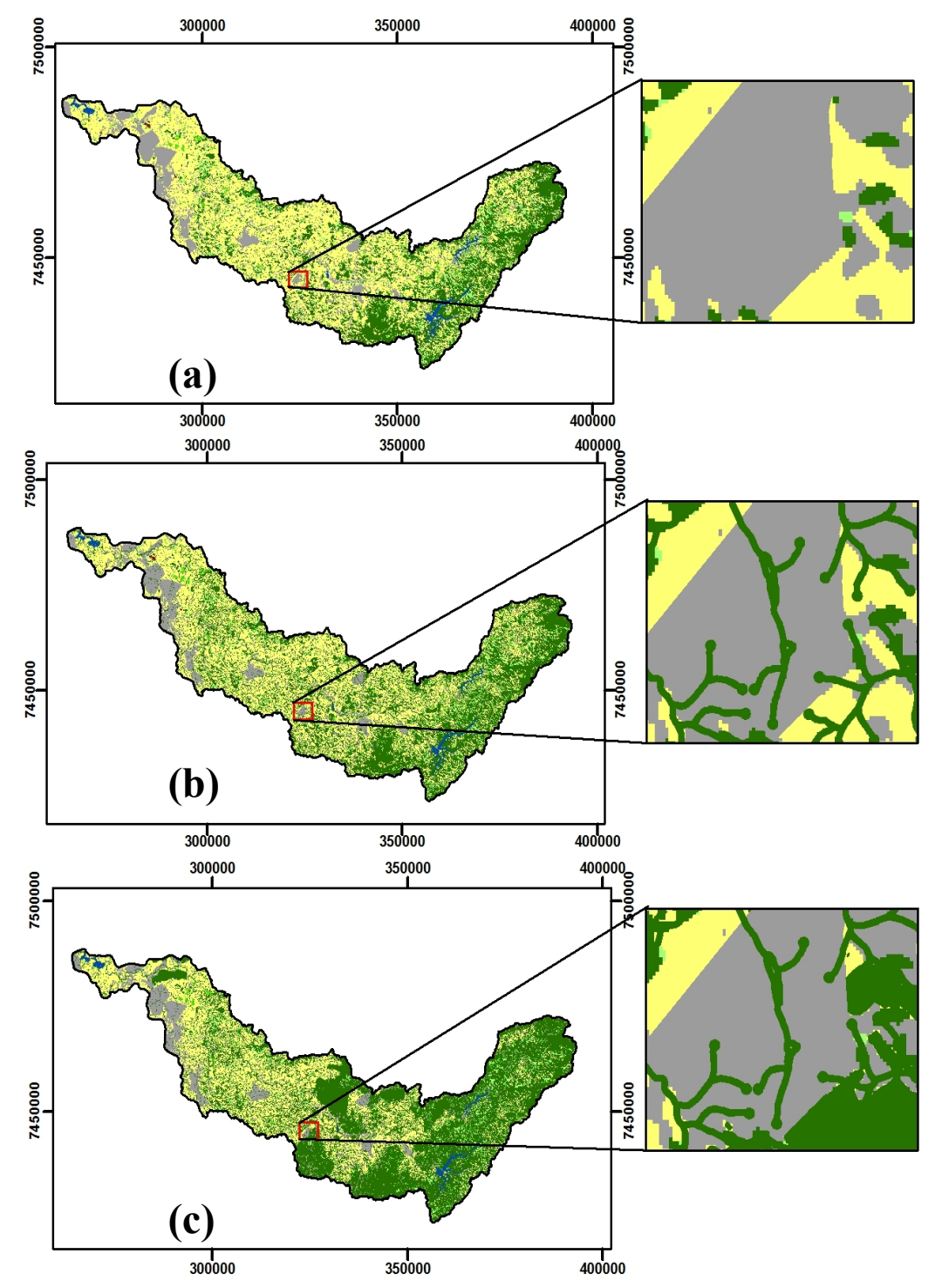

Land-use classes
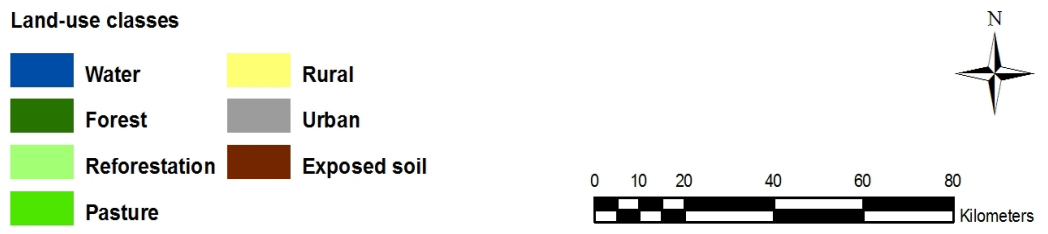

Figure 4: Land-use simulated for Tendency Scenario (a), Management Scenario (b) and Conservation Scenario (c). 
measure allows the revitalization of rivers and the establishment of parks and other leisure areas.

In the Conservation Scenario (represented by item (c) on the image), there were improvements not only to the ecosystems, but new perspectives on biodiversity conservation, carbon storage and human well-being improvements were added.

From the results of the scenarios and from theory review, it is possible to affirm that environmental planning is better established when considering forest best management practices and ecological principles [1, 25, 26].

Therefore, the integration between urban and social aspects must be considered, and also spatial heterogeneity and human and natural ecosystems.

Alberti [27] proposes that ecological conservation should be done not only in areas of high natural significance, but also in urban areas and environs, as a measure of maintenance of ecosystem function from both a local and global perspective.

This approach, also called Urban Green Infrastructure, allows sustainable urban growth, as well as making environmental conservation, maintenance of ecosystem services and improvements of life quality of citizens feasible [14, 28].

Finally, in a context of future climatic uncertainties, one measure of effective adaptation of cities is to use ecological principles on the management of the territory, such as spaces with natural characteristics that provide cooling and storage, as well facilitating infiltration [13, 29-31]. As an innovative approach, risk-transfer mechanisms, such as insurance funds for hydrologic risk adaptation under climatic uncertainties can be explored at the scale of river basins $[32,33]$.

\section{Conclusion}

It was observed that the environmental indicators were representative and very useful, both for the analysis and scenario elaboration.

The Conservation Scenario achieved the best results after an overview of the scenarios.

It is important to mention that in this scenario, the human occupation on the basin is not prohibited, but it is necessary that this occupation should take place in an organized and sustainable way.

Recommendations for future studies are coupling hydrologics into this analysis, as a tool to simulate hydrological conditions from future land-use change scenarios in river basins. In this way, risk-transfer strategies, at a river basin scale, can play an important role in the adaptation and resilience of communities facing hydrological extremes.

In addition, efforts should be made on the restoration, recuperation and rehabilitation of rivers and terrestrial ecosystems on key watersheds.

\section{Acknowledgements}

- The Centre of Exact and Environmental Sciences and Technologies (CEATEC) of the Pontifical Catholic University of Campinas, Campinas, Brazil. 
- FAPESP-IAV project number 2008/58161 “Assessment of Impacts and Vulnerability to Climate Change in Brazil and Strategies for Adaptation Options".

- The Hydraulics and Sanitation Department (SHS) of the Engineering School of São Carlos (EESC), University of São Paulo (USP), São Carlos, Brazil.

\section{References}

[1] Pickett S. T. A., Cadenasso M. L., Grove J. M., Boone C. G., Groffman P. M., Irwin E., Kaushal S. S., Marshall V., McGrath B. P., Nilon C. H., Pouyat R. V., Szlavecz K., Troy A. and Warren P. (2011). Urban ecological systems: Scientific foundations and a decade of progress. Journal of Environmental Management, 92(3), 331-362.

[2] UNFPA (United Nations Population Fund). (2007). Unleashing the Potential of Urban Growth. State of World Population 2007. UNFPA, New York.

[3] Pompêo C. A. (1999). Development of a state policy for sustainable urban drainage. Urban Water, 1(2), 155-160.

[4] Arnold Jr. C. L. and Gibbons C. J. (1996). Impervious Surface Coverage: The Emergence of a Key Environmental Indicator. Journal of the American Planning Association, 62(2), 243-258.

[5] Ross J. L. S. (1994). Análise Empírica da Fragilidade dos Ambientes Naturais e Antropizados. Revista do Departamento de Geografia, 8, 63-74.

[6] Tricart, J. Ecodinâmica. IBGE/SUPREN, Rio de Janeiro.

[7] Paul M. J., Meyer L. (2001). Streams in the urban landscape. Annu. Rev. Ecol. Syst., 32, 333-365.

[8] Chin A. (2006). Urban transformation of river landscapes in a global context. Geomorphology, 79(3), 460-487.

[9] Groffman P. M., Boulware N. J., Zipperer W. C., Pouyat R. V., Band L. E. and Colosimo M. F. (2002). Soil Nitrogen Cycle Processes in Urban Riparian Zones. Environ. Sci. Technol., 36(21), 4547-4552.

[10] White M. D. and Greer K. A. (2006). The effects of watershed urbanization on the stream hydrology and riparian vegetation of Los Peñasquitos Creek, California. Landscape and Urban Planning, 74(2), 125-138.

[11] Costanza R., d'Arge R., de Groot R., Farberk F., Grasso M., Hannon B., Limburg K., Naeem S., O’Neill R. V., Paruelo J., Raskin R. G., Suttonkk P. and van den Belt M. The value of the world's ecosystem services and natural capital. (1997). Nature, 387(6630), 253-260.

[12] Bolund P. and Hunhammar S. (1999). Ecosystem services in urban areas. Ecological Economics, 29(2), 293-301.

[13] McEvoy D., Lindley S. and Handley J. (2006). Adaptation and mitigation in urban areas: synergies and conflicts. Proceedings of the Institution of Civil Engineers. Municipal Engineer, 159(4), 185-191.

[14] UN-Habitat (United Nations Human Settlements Programme). (2009). Planning Sustainable Cities. Global Report on Human Settlements 2009. Earthscan, London. 
[15] Santos R. F. (2004). Planejamento Ambiental: teoria e prática. Oficina de Textos, Sao Paulo.

[16] Sánchez L. H. (2008). Avaliação de Impacto Ambiental - conceitos e métodos. Oficina de Textos, Sao Paulo.

[17] Mendiondo E. M., Ohnuma Jr A. A., Benini, R. M., Peres R. B. (2004). Metodologia simplificada de cenários de planejamento para a recuperação ambiental de bacias urbanas. In: XXI Congresso Latinoamericano de Hidráulica. IAHR/AIPH, São Paulo.

[18] Bevilacqua J. E., Menegon Jr N. and Bressan Jr H. (1999). Bacia do Rio Atibaia: Relatório Técnico Preliminar. CETESB, São Paulo.

[19] SMA/CRH (2009). Situação dos Recursos Hídricos no Estado de São Paulo: Ano base 2007. SMA, Sao Paulo.

[20] SHS Consultancy and Engineering Projects. (2006). Plano de bacias hidrográficas 2004-2007 dos rios Piracicaba, Capivari e Jundiaí. Final Report. Piracicaba, Brazil.

[21] Laurentis G. L., Demanboro A. C., Conforti T. B., Adami S. F, Bettine S. C. (2009). Diagnóstico ambiental da bacia hidrográfica do Rio Atibaia, SP, utilizando ferramentas de geoprocessamento. In: II Seminário de Recursos Hídricos da Bacia Hidrográfica do Paraíba do Sul, Taubaté, pp. 89-96.

[22] Laurentis G. L. (2008). Elaboração de cenários como suporte ao Planejamento Ambiental da Bacia Hidrográfica do Rio Atibaia. Graduation Conclusion Work. Pontifical Catholic University of Campinas, Campinas.

[23] Laurentis, G. L., Demanboro, A. C., Mendiondo, E. M., Aquino, S. (2011). Watershed management based on scenarios of green areas restoration related to urban drainage. In: 12th International Conference on Urban Drainage, 2011, Porto Alegre-RS.

[24] Brazil (1965). Brazilian Federal Law number 4.771/65.

[25] Matteo M., Randhir T. and Bloniarz D. (2006). Watershed-Scale Impacts of Forest Buffers on Water Quality and Runoff in Urbanizing Environment. Journal of Water Resources Planning and Management, 132(3), 144-152.

[26] Yang B. and Li M. (2010). Ecological engineering in a new town development: Drainage design in The Woodlands, Texas. Ecological Engineering, 36(12), 1639-1650.

[27] Alberti M. (2010). Maintaining ecological integrity and sustaining ecosystem function in urban areas. Current Opinion in Environmental Sustainability, 2(3), 178-184.

[28] UN-Habitat (United Nations Human Settlements Programme). (2011). Cities and Climate Change: Policy Directions. Global Report on Human Settlements 2011. Earthscan, London.

[29] Whitford V., Ennos A. R. and Handley J. F. (2001). "City form and natural process"-indicators for the ecological performance of urban areas and their application to Merseyside, UK. Landscape and Urban Planning, 57(2), 91-103.

[30] Mell I. C. (2009). Can green infrastructure promote urban sustainability? Proceedings of the Institution of Civil Engineers. Engineering Sustainability, 162(1), 23-34. 
[31] Gill S. E., Handley J. F., Ennos A. R. and Pauleit S. (2007). Adapting Cities for Climate Change: The Role of the Green Infrastructure Built Environment, 33(1), 115-133.

[32] Laurentis, G. L., Pimentel, I. M. C., Bressiani, D. A., Mendiondo, E. M. (2011). Aplicabilidade de modelos de transferência de riscos hidrológicos como estratégia de adaptação a eventos extremos. In: XIX Simpósio Brasileiro de Recursos Hídricos, 2011, Maceió-AL.

[33] Laurentis G. L. (2012). Modelo de Transferência de Riscos Hidrológicos como Estratégia de Adaptação às Mudanças Globais Segundo Cenários de Vulnerabilidade dos Recursos Hídricos. Master's Dissertation, Engineering School of São Carlos, University of São Paulo, São Carlos. 